\title{
JUDICIAL GLOBALISATION. A NEW MODEL OF NORTH-SOUTH RELATIONS FOR THE 21ST CENTURY?
}

\author{
Víctor NAVARRETE*
}

RESUMEN: Este trabajo presenta una evaluación crítica del fenómeno llamado globalización judicial, como lo describen algunos autores neoliberales, tales como Robert O. Keohane, Andrew Moravcsik y Anne Marie Slaughter. De acuerdo con estos pensadores, la globalización judicial creará una comunidad legal global (un lenguaje legal común), y convertirá a los cuerpos judiciales alrededor del mundo en discretos, pero importantes centros de poder que reducirán los márgenes de maniobra de la política exterior por parte de las instituciones gubernamentales. Este ensayo demostrará que esta teoría responde a una agenda política particular, por la cual una elite transnacional emergente pretende imponer sus intereses sobre los países en desarrollo.

ABSTRACT: This work provides a critical assessment of judicial globalisation as described by neo-liberal scholars such as Robert O. Keohane, Andrew Moravcsik and Anne-Marie Slaughter. According to them, judicial globalisation will create a global community of law and will transform adjudicative bodies around the World into discrete but significant centres of power that will reduce the margins for political foreign policy manoeuvres by governmental institutions. This essay will demonstrate that this theory responds to a particular political agenda by which an emerging transnational elite pretend to impose their interests over developing countries.

RÉSUMÉ: Cet travail présent une évaluation critique du phénomène appelle globalisation judiciaire comme est décrit pour quelques auteurs neo-libérales comme Robert $O$. Keohane, Andrew Moravcsik y Anne Marie Slaughter. En accordance avec ces penseurs la globalisation judiciaire créera une communauté légale globale (un langage commun) et convertira aux corps judiciaire autour du monde en discrets, mais importants centres de pouvoir qui rediront les marges de manoeuvre de la politique extérieur pour part des institutions gouvernementales. Cet travail prouvera que cet théorie correspond a un agenda politique particulaire, pour laquelle un élite transnational émergent prétend impose ses intérêt sur les pays en développement.

* Master of Laws en la Harvard Law School y Master of Studies in International Relations en la Wolfson College, University of Cambridge. 


\section{SUMARIO: I. Introduction. II. A Liberal Approach to Judicial Globalisation. III. A Critique to the Liberal Approach.}

\section{INTRODUCTION}

The end of the East-West confrontation and the process of globalisation represented an extraordinary opportunity to increase the well being of many people around the world, but they also posed new threats to $\mathrm{Hu}-$ mankind. The delicate political balance that prevailed in the international community for more than forty years was broken, and a new world (dis) order has emerged in which liberal values seem to have prevailed.

Democracy, free markets, the rule of law, and respect for human rights have been recognised by most western countries as the pillars of good governance. This new era of Liberalism has led to the strengthening of the international human rights regime and to the proliferation of free trade agreements between industrialised and developing nations. There has also been a democratising process in nations where authoritarian or totalitarian governments ruled for many decades.

However, and in spite of all the alleged benefits that Liberalism has brought, what is actually emerging is "a new political model of NorthSouth relations for the twenty-first century". ${ }^{1}$

The end of a bipolar world has led to the outburst of intrastate and regional conflicts throughout the world. Extreme forms of nationalism and the lack of an effective institutional framework that would guarantee the lawful and orderly exercise of these political and economic liberties have resulted in genocides and the proliferation of international criminal organisations. The gap between the rich and the poor has also widened, and misery, ignorance and social injustice are spreading throughout the world at an incredible speed.

As a response to these new trends, there has been a considerable expansion of the international judiciary. Some authors refer to this process as judicial globalisation. This work demonstrates that contrary to what liberals argue, judicial globalisation is not a process that will necessarily liberate people from oppression or violence. It may be regarded as just another tool by which the core regions of the capitalist world system

1 Robinson, William I., Promoting Polyarchy: Globalization, US Intervention, and Hegemony, Cambridge, Cambridge University Press, 1998, at 7. 
exercise a new form of non-coercive domination over peripheral and semi-peripheral regions, in the context of emergent transnational configurations. $^{2}$

In order to asses whether judicial globalisation is in fact a new form of domination of the South by the North - or more specifically, of the marginalized by global capitalist elites - it is important to analyse the aggrandisement of the international judiciary, as well as the pertinence and shortfalls of the Liberal approach to this phenomenon.

It is an undisputed truth that during the last decade, the international judiciary has grown steadily. New courts, tribunals and quasi-judicial bodies have recently been created and the existing ones have been strengthened. For instance, international criminal tribunals have flourished during the 1990s, and institutions like the Inter-American Court of Human Rights have developed more open-ended and flexible mechanisms in order to protect individual rights throughout the American continent.

According to liberal scholarship, there also seems to be a tendency to move from the traditional international dispute resolution processes, which centred on states as principal actors, to a more flexible model in which individuals, national courts and non-governmental organisations actively participate in a judicial solution.

Judicial globalisation is a complex phenomenon. It not only involves heightened participation of non-state actors, but is also characterised by increased interactions among different judicial bodies around the world. In Europe, for instance, national courts have established an ever-closer dialogue with both the European Court of Human Rights and the European Court of Justice. However, these vertical relations that are typical of supranational systems tell only part of the story. Perhaps the most salient features of judicial globalisation - as understood by liberals - include the emergence of "judicial comity" in transnational litigation; the practice of Constitutional cross-fertilisation among judges from different nationalities, with national courts integrating ideas, principles and modes of argument that have been created and expounded by foreign courts; 
and finally, the multiplication of "face-to-face" meetings among judges around the world. ${ }^{3}$

From a neo-liberal point of view, judicial globalisation does not refer to the construction of a supranational or even an international judicial system; most existing judicial bodies are not functionally linked to one another.

This would have been the dream of both the liberal idealists of the early Twentieth century and the supporters of an Orwellian world government.

The neo-liberal concept of globalisation depicts a diffuse force that is building consensus among judges around the world regarding universally valid legal principles, and the way in which they must be applied. Under this theory, a common judicial enterprise creates a "global community of law" through an incremental and multilevel process. This community of law evolves as judges become more loyal to the rule of law (as understood in the West) than to the legal principles in their own countries.

This neo-liberal approach tends to take for granted some of its main arguments or premises and simply ignores other issues that are equally important to the construction of a real community of law (if that is ever possible). It assumes that Liberalism has finally beaten all other ideologies and that the state is no longer a unitary actor in international relations. For this theory, the state is becoming a disaggregated entity composed of its component political institutions, in which courts can act more or less freely without deference to their own governments. This paradigm also overlooks the resistance that this kind of globalisation may generate among peoples who have either been marginalized by poverty - or any other reason - or do not share Western cultural values. Moreover, it ignores the resistance that may be generated within liberal democracies. Democracy has its own paradoxes that can lead a country to an isolationist attitude in relation to external influences such as judicial cooperation. Finally, the theory focuses only on two legal fields: $\mathrm{Hu}-$ man Rights and International Trade. Nothing is said about economic, social, or cultural rights or about common global concerns. As in any theory, assertions and silences are equally important; this one represents

3 See Slaughter, Anne-Marie, "Judicial Globalization”, 40 Va. J. Int'l L. 1103, verano de 2000 . 
an effort to explain reality, but also to promote a specific political agenda. In other words, theories are socially constructed to match the desired reality. Judicial globalisation is what scholars say it is, and by monopolizing the discourse, this kind of liberal thought can indeed impact the way international judicial bodies are conceived. More importantly, it can influence the development and behaviour of these institutions.

This work provides a critical assessment of judicial globalisation as described by neo-liberal scholars such as Robert O. Keohane, Andrew Moravcsik and Anne-Marie Slaughter.

It is not clear whether liberal judicial globalisation will succeed. It assumes - as does neo-liberalism - that the promotion of human rights, democracy and free markets are one and the same thing. It also postulates that history and ideological diversity have come to an end: Liberal democracy stands alone as the only possible way to organise political communities. This blind faith in liberal democracy may be more clearly understood in Francis Fukuyama's The End of History and the Last Man. Fukuyama believes - as did Hegel and Marx - that the evolution of human societies would end when the deepest and most basic aspirations of humankind were satisfied. ${ }^{4}$ A look at the newspapers reveals that we are still very far from this evolutionary stage.

The future is uncertain. Whilst judicial globalisation might unite many people on several issues, it will spark other fragmentation processes that further widen the gap between the North and the South. ${ }^{5}$ Due to the great social inequality this "new world" is generating, it would not be surprising if many developing countries react with greater nationalism and closure to outside influences. For many of these nations, the unitary state still represents a modernising element. ${ }^{6}$

On the other hand, as previously mentioned, liberals overemphasise the importance of individual rights - especially property rights - for a very simple reason: They are instrumental in ensuring the development and expansion of a global capitalist economy.

4 Fukuyama, Francis, El fin de la historia y el último hombre, Barcelona, Planeta, 1992, at $12,13$.

5 Clark, Ian, Globalization and Fragmentation: International Relations in the Twentieth Century, Nueva York, Oxford University Press, 1997, at 186.

6 Ibidem, at 195. 
Certainly, some aspects of liberal judicial globalisation are worth defending. No one doubts the importance of protecting human rights; the problem arises when one must choose among them. Some advocates emphasise individual freedoms, whilst others promote equality as the ultimate goal. Humanity cannot survive without minimum rights in both areas. Furthermore, some societies do not even plot these principles in terms of rights. Democracy - an indispensable element for the liberal theory of judicial globalisation - might be the least perverse way of government, but a democratic decision might include an absolute reluctance to support a liberal vision of the world. A free economy has been demonstrated as the best way to produce wealth. However, asymmetries amongst national economies, and the logic of markets, have increased the differences between the poor and the rich, especially since the end of the Cold War. In principle, the idea that judges can significantly contribute to a world ruled by law and not by force is laudable. In this sense the liberal approach is more promising than Realism, which is still fixated on a state-centred international system. However, in judicial globalisation as understood by liberals, in which there will be winners as well as losers, the relevant question is: Who benefits from it? Northern capitalist elites, or Humankind as a whole?

\section{A LIBERAL APPROACH TO JUDICIAL GLOBALISATION}

For some liberal scholars, judicial globalisation is an unprecedented phenomenon that will alter international relations as it creates a new paradigm for dispute resolution both domestically and internationally. The thrust of their arguments is that courts will eventually become centres of international power that will influence world politics in a way they have never done before. ${ }^{7}$

This section presents one of the most comprehensive and overarching theories related to this matter. Ideas of some of the most important liberal authors, such as Cesare Romano, Robert Keohane, Andrew Moravcsik and Laurence Helfer, will be presented here; however, the

7 See: Goldstein, Judith et al., "Legalization and World Politics", International Organization 54, 3, verano de 2000, at 385-399; Slaughter, Anne-Marie, "Judicial Globalization", supra note 3; and Keohane, Robert O. et al., "Legalized Dispute Resolution: Interstate and Transnational", International Organization 54, 3, verano de 2000, at 457-488. 
analysis will focus primarily on the work of Anne-Marie Slaughter, who coined the term "judicial globalisation". ${ }^{8}$

According to Slaughter, judicial and quasi-judicial bodies are increasingly interacting across, above and below borders. Basically, there are four different categories in which judicial interactions are augmenting and changing: ${ }^{9}$ Relations between national courts and supranational jurisdictions; interactions between courts in transnational litigation, proper; constitutional cross-citation; and exchanges between judges of different nationalities.

\section{Shift from interstate dispute resolution processes to a transnational dispute resolution model}

According to some liberal authors,${ }^{10}$ the role of the state in supranational adjudication is diminishing. The unitary state is losing control over

8 Bibliography on the Liberal perspective of judicial globalisation includes, but is not limited, to the following: Goldstein, Judith et al., supra note 7; Helfer, Laurence R. and Slaughter, Anne-Marie, "Toward a Theory of Effective Supranational Adjudication", 107 Yale L. J. 273, noviembre de 1997; Keohane, Robert O. et al., "Legalized Dispute Resolution: Interstate and Transnational", supra note 7; Petersmann, Ernst-Ulrich, "Time for a United Nations 'Global Compact' for Integrating Human Rights into the Law of Worldwide Organizations: Lessons from European Integration", European Journal of International Law, vol. 13, núm. 3, 2002, pp. 621-651, http://www.ejil.org/journal/Vol13/ No3/art1.pdf; Romano, Cesare P. R., "The Proliferation of International Judicial Bodies: The Pieces of the Puzzle", 31 N.Y.U.J. INT'L L. \& POL. 709, 1999; Slaughter, Anne-Marie, "International Law in a World of Liberal States", European Journal of International Law, vol. 6, núm. 4, 1995, http://www.ejil.org/journal/Vol6/No4/index.html; Slaughter, Anne-Marie, "Judicial Globalization", supra note 3; and Slaughter, Anne-Marie, "The Real New World Order", Foreign Affairs, vol. 76, núm. 5, septiembre-octubre de 1997, pp. 183-197. Critiques to this approach include: Alston, Philip, "The Myopia of the Handmaidens: International Lawyers and Globalization", European Journal of International Law, vol. 8, núm. 3, 1997, pp. 435-448, http://www.ejil.org/journal/Vol8/No3/art4. html; Alston, Philip, "Resisting the Merger and Acquisition of Human Rights by Trade Law: A Reply to Petersmann", European Journal of International Law, vol. 13, núm. 4, 2002, pp. 815-844, http://www.ejil.org/journal/Vol13/No4/art2.html; Knop, Karen, "Here and There: International Law in Domestic Courts", 32 N.Y.J.INT'L L. \& POL. 501, 2000; Sur, Serge, "The State between Fragmentation and Globalization", European Journal of International Law, vol. 8, núm. 3., 1997, pp. 421-434, http://www.ejil.org/journal/Vol8/ No3/art3.html.

9 Slaughter, Anne-Marie, "Judicial Globalization", supra note 3, at 1104.

10 See Keohane, Robert O. et al., "Legalized Dispute Resolution: Interstate and Transnational", supra note 7, at 457-488. 
both the endogenous and exogenous dynamics of supranational adjudication. Relations between national courts and supranational jurisdictions are changing and becoming more important than those between national governments and the international judiciary. The classical model of international dispute resolution is dramatically changing.

Traditionally, International Law has been conceptualised as a normative framework that regulates relationships only between states. Individuals are not considered to be subjects of this legal system. In this model, states behave as unitary sovereign actors that can solve their disputes in supranational courts and tribunals, which have been created by them, directly or indirectly, through treaty-making processes.

States control these judicial bodies in several ways. First, states are usually the unique entities, which are allowed to have access to international adjudicative processes. Second, states usually designate the judges that will sit on these tribunals. Third, states have the discretion to enforce or fail to enforce the decisions of these international courts. Fourth, states control the international legal process and its consequences in domestic law. This paradigm for solving disputes has been called Interstate Dispute Resolution (IDR). ${ }^{11}$

It can be argued that this type of international dispute resolution model has never really existed, at least since the beginning of the Cold War. For example, even the International Court of Justice (ICJ), which became operational in 1946, gives access to non-state actors such as the General Assembly or the Security Council in matters related to advisory opinions. It could also be asserted that judges are not designated directly by member states of the United Nations, but by the General Assembly and the Security Council. ${ }^{12}$ Further, states can always opt out of the Court's jurisdiction if they are not willing to submit their disputes for a judicial solution. Finally, there is no effective supranational mechanism to enforce the ICJ rulings. Theoretically, the Security Council is empowered to enforce them with the use of force, if necessary. However, the very architecture of the UN justice system favours political solutions

11 Ibidem, at 457.

12 Article 4 (1) of the Statute of the International Court of Justice establishes: "The members of the Court shall be elected by the General Assembly and by the Security Council from a list of persons nominated by the national groups in the Permanent Court of Arbitration", http://www.icj-cij.org. 
over strictly juridical outcomes. There cannot be a legalised solution when the five permanent members of the Security Council maintain power to veto a binding decision of the ICJ. ${ }^{13}$

Despite of these exceptions, there is no obstacle in conceiving this sort of dispute resolution model as one that is deferential to sovereign countries. In other words, it is a state-centred paradigm propelled by the logic of power politics rather than judicial principles. As some authors hold, ${ }^{14}$ IDR is an ideal type of dispute resolution and consequently it is impossible to find an existing court or tribunal that neatly fulfils all of its requirements. But such models serve to explain reality through abstract and relatively simple principles.

Since the end of the Cold War, there has been a tendency to move from IDR to a more flexible mechanism that has been called Transnational Dispute Resolution (TDR). TDR is a dispute resolution process in which non-state entities have access to international forums. In this scheme, states are usually unable to designate the judges that will sit at international tribunals. In addition, States tend to enforce the rulings of international judicial or quasi-judicial bodies regardless of their binding or unbinding character. In other words, it is irrelevant whether the adjudicative body's resolution is binding or just persuasive. In this model, there are political as well as legal mechanisms at work that punish nations when they fail to comply with these judicial decisions. The existence of this legal process is not new, but it has been reinvigorated and strengthened since the collapse of Communism. Most of the recently created judicial and quasi-judicial bodies have been constructed according to the TDR model.

13 See the 1984-1991 ICJ case regarding the dispute between Nicaragua and the United States, in which the US was ordered by the International Court of Justice to make reparations to Nicaragua for all the destruction implied in the military and paramilitary aid given to the Contras. The Security Council should have enforced the Court's ruling, but since the US has a veto power in that UN body, the "political" solution prevailed over legal obligations. The problem was solved through negotiation between an economically devastated country and the most powerful nation in the world. Case Concerning the Military and Paramilitary Activities in and against Nicaragua (Nicaragua v. United States of America). International Court of Justice. Judgement of 27 June 1986 (Merits), http://www.icj-cij.org.

14 Keohane, Robert O. et al., "Legalized Dispute Resolution: Interstate and Transnational", supra note 7 , at 457-459. 
The main difference between IDR and TDR is that in the latter "access to courts and tribunals, and the subsequent enforcement of their decisions, are legally insulated from the will of individual national governments" ${ }^{15}$ In contrast to IDR, TDR allows individuals and other actors in civil society to participate in international judicial proceedings. It also makes it difficult for states not to comply with a ruling issued by a supranational judicial body.

Keohane, Moravcsik and Slaughter argue that the formal legal differences between IDR and TDR "have significant implications for the politics of dispute settlement and therefore for the effects of legalization in world politics". ${ }^{16}$

According to this liberal approach, the international judiciary will continue to evolve incrementally toward TDR.

The prototypical examples of TDR are the two major European Courts, the ECJ and the ECHR. Their effectiveness is due to their very unique history and the particular political context in which they have evolved. However, liberal scholars ${ }^{17}$ assert that this sort of supranational adjudication can be extrapolated to other latitudes. Helfer and Slaughter argue that the UN Human Rights Committee (UNHRC) could follow some of the patterns that have made supranational adjudication in Europe so effective. They also believe that other dispute resolution bodies, e.g. the WTO, NAFTA panels, the IACHR and the ICC, could evolve similarly. ${ }^{18}$ For example, the IACHR has used to some extent and will probably continue to use the reasoning and interpretative methodologies previously developed by the ECHR. ${ }^{19}$

In the case of UNHRC, Helfer and Slaughter state that "the Committee should be able to replicate another dimension of the European experience: the construction of a 'community of law'". ${ }^{20}$ Communities of law are not constituted only by states, but by networks of individuals, domestic courts, lawyers, governmental officials, academics, and NGOs,

15 Ibidem, at 458.

16 Ibidem, at 457.

17 Helfer, Laurence R. and Slaughter, Anne-Marie, "Toward a Theory of Effective Supranational Adjudication", supra note 8.

18 Ibidem, at 338.

19 Slaughter, Anne-Marie, "Judicial Globalization", supra note 3, at 1110.

20 Helfer, Laurence R. and Slaughter, Anne-Marie, "Toward a Theory of Effective Supranational Adjudication", supra note 8, at 389. 
among others. In order to build these communities, it is necessary create or strengthen legally valid channels of communication by which these actors can articulate and disseminate norms, principles and jurisprudence issued by supranational judicial or quasi-judicial entities. The idea is to find new legal formulations that would "maximize the impact of supranational decisions". ${ }^{21}$ The first step to create this common language would be to link the UNHRC to the ECHR jurisprudence so that the body of law produced by the former would converge, where appropriate, with that of the latter. ${ }^{22}$

But this dialogue is not limited to interactions among supranational entities. Communication of this sort is also taking place between supranational courts and domestic tribunals. For instance, in 1995 the South African Supreme Court considered arguments and resolutions issued by the ECHR, in declaring the death penalty as unconstitutional. A similar approach toward supranational jurisprudence was observed by the Supreme Court of Zimbabwe and by the British Privy Council in important decisions regarding the protection of human rights. ${ }^{23}$ The Supreme Court of Zimbabwe considered the reasoning of the ECHR in declaring that corporal punishment of an adult constitutes cruel and unusual punishment, and that the same punishment was unconstitutional if applied to a juvenile offender. ${ }^{24}$ Similarly, the British Privy Council, sitting as the Constitutional Court of Jamaica, commuted a Jamaican death penalty to life imprisonment, based on the ECHR's decision in Soering v. United Kingdom. ${ }^{25}$

21 Idem.

22 Idem.

23 Slaughter, Anne-Marie, "Judicial Globalization", supra note 3, at 1110.

24 See cases Ncube v. State, 1988 (2) SA 702 (citing Tyrer v. United Kingdom, 26 Eur. Ct. H.R. (ser. A) (1978)); Juvenile v. State, Judgment núm. 64/89, Crim. App. núm. 156/88 (Zimb. 1989) (citing both Tyrer v. United Kingdom and Campbell \& Cosans v. United Kingdom, 48 Eur. Ct. H.R. (ser. A) (1982)).

25 See Case Pratt v. Attorney General for Jamaica, 4 All E.R. 769 (P.C. 1993) (en banc); Soering v. United Kingdom, 161 Eur. Ct. H.R. (ser. A) (1989). In this case, the ECHR held that extradition of a prisoner who might be sentenced to the death penalty in the requiring state violated Article 3 of the European Convention, which states that: No one shall be subjected to torture or to inhuman or degrading treatment or punishment. See Convention for the Protection of Human Rights and Fundamental Freedoms as amended by Protocol núm. 11, with protocols nos. 1, 4, 6, 7, 12 and 13. http://www.echr. coe.int/Convention/webConvenENG.pdf. 
So far this section has analysed the supranational aspects of this sort of judicial globalisation. It has also introduced the issue of a nascent global community of law, which also reaches the domestic dimension and the transnational level proper. Further elaboration upon this topic is presented in the following subsection.

\section{Increased horizontal interaction among different judicial bodies around the world}

The emergence of new dynamics in supranational adjudication is an important part of judicial globalisation; however, horizontal relations between national courts are instrumental in building a global community of law. The modes in which domestic courts relate to each other are changing dramatically.

Economic globalisation and the reassertion of individual rights have had a strong impact on the way in which domestic courts are interacting today. In an increasingly interdependent world, investment by one company may be disseminated in several countries; likewise, the processes of production and distribution are fragmented throughout the globe. Most economic transactions are unthinkable without the participation of people and institutions of different nationalities. ${ }^{26}$ The magnitude, velocity and multiplicity of the global economy have increased transnational litigation, as well as the number of potential domestic courts for solving disputes. The traditional norms of private international law and arbitration fall short of the requirements of this new economic reality. Today, disputants of different nationalities must rely on domestic courts to solve effectively their controversies. It has become indispensable that national courts modernise and develop a common language in order to meet the requirements imposed by globalisation and economic integration. This is the reason why domestic courts - more than ever- must offer dispu-

26 For a general discussion on globalisation, see: Clark, Ian, supra note 5; Held, David et. al., Global Transformations: Politics, Economics and Culture, Stanford, California, Stanford University Press, 1999; Hirst, Paul and Thompson, Grahame, Globalization in Question: The International Economy and the Possibilities of Governance, Cambridge Polity Press, 2000, at 275-280; Kellner, Douglas, "Theorizing Globalization", http://www.gseis.ucla.edu/faculty/kellner/papers/theoryglob.htm; and Keohane, Robert O. and Nye, Joseph, Governance in a Globalizing World, 2000. http://www.ksg.har vard.edu/visions/publication/globalizing_intro.doc. 
tants three key elements: predictability, stability and the satisfaction of mutual expectations. ${ }^{27}$ National courts are recognising their instrumental role as ultimate gatekeepers of successful economic integration processes. This role has sparked a new concept of judicial comity, in which domestic judicial bodies are deferring to other countries' national courts rather than to foreign law or foreign national interests. In other words, national courts have become increasingly deferential to professional institutions that will solve the dispute through fair procedures, honestly and competently. At the same time, there is a growing conviction that domestic courts in different nations serve as equally valid adjudicative institutions, and that courts have been created to protect individual rights.

It is evident that this conception of judicial comity assumes that much work is needed to harmonise rules of procedure in domestic fora around the world. Would this harmonisation effort be seen as a new means of dominance by the rich over the poor? Is this doctrine also overly preoccupied with the promotion of global capitalism, to the detriment of other fundamental rights and freedoms? This question will be addressed in the next section.

Judicial comity is only one of several "horizontal" mechanisms to create a global community of law. Transjudicial interaction also takes place in the form of constitutional cross-fertilisation. Constitutional judges are borrowing fundamental legal principles and arguments from the highest tribunals in other countries to support their own resolutions. In the example given above, regarding the death penalty decision of the South African Court, the judges not only consulted ECHR jurisprudence but also analysed the arguments and decisions of the highest tribunals of the United States, Germany, Canada, and India, among others. According to Slaughter this kind of dialogue is "the most informal level of transnational judicial contact. While opinions rendered by the courts of other national legal systems are never binding, national constitutional courts turn to foreign decisions for different perspectives on similar issues". ${ }^{28}$

This cross-fertilisation or cross-citation is supposed to enhance the argumentative arsenal of all judges around world. Adjudicators are not

27 Slaughter, Anne-Marie, "Judicial Globalization", supra note 3, at 1113.

28 Ibidem, at 1116. 
required to issue their rulings exactly as constructed in other countries. This exchange is important because several universally valid principles can be found in most national legal systems. Whilst these principles cannot be extrapolated literally, they can be adapted to the legal norms and culture of the nation that is adopting them. This issue is also problematic, as it will be shown in next section.

Finally, the third kind of horizontal interaction among national courts is a meta-juridical form of communication: Judges of different nationalities are holding meetings to share experiences and to learn from one another. Recently, there have been myriads of international conferences and seminars to accomplish this goal. Some of these exchanges have been institutionalised, i.e. the Organization of the Supreme Courts of the Americas, the Worldwide Common Law Judiciary Conference, and the Association of Judges of the Baltic States. ${ }^{29}$

These meetings are organised and promoted by NGOs and professional associations such as the human rights organisation called InterRights (based in London) and the American Bar Association (ABA). Law schools and academics also participate. ${ }^{30}$

It appears that one of the most important features of judicial globalisation is that judges are developing a sense of belonging and empowerment as they proactively participate in a common enterprise: the strengthening of rule of law across the world. This Liberal perspective depicts adjudicators as individuals who are more loyal to this goal than to their own national governments. To assert that judges are becoming more loyal to legal principles than to their own country's national interest, necessarily implies a change in the traditional understanding of sovereignty. In a Westphalian order, states are the only relevant actors in international law. A state exercises supreme authority over the population within its own territory and, presumably, over all of its nationals as well. Under this model, the nation-state is supposed to be independent from other systems, i.e. states or international organisations. Consequently, the state expresses its will through its agents (i.e. judges) in a monolithic way. Judges can only express the will of the state to which they belong. If it is really true that judges are increasingly committed to enforcement of universal values that do not necessarily bind their governments from a

30 Ibidem, at 1121. 
legal standpoint, then the State must be losing its monolithic structure. This fragmentation process implies the emergence of a different understanding of the structure and functions that contemporary states display.

In order to understand all the transformations described in this section, it is necessary to analyse the terms in which this particular strand of liberal scholarship plots sovereignty.

\section{The changing concept of sovereignty: The fragmentation} of the State

Contrary to what many globalizers think, the State is not vanishing with globalisation; it has only stopped acting as a monolithic structure. In this regard, Slaughter argues:

The state is not disappearing; it is disaggregating into its separate functionally distinct parts. These parts - courts, regulatory agencies, executives, and even legislatures - are networking with their counterparts abroad, creating a dense web of relations that constitutes a new, transgovernmental order. Today's international problems - terrorism, organized crime, environmental degradation, money laundering, bank failure, and securities fraud - created and sustain these relations. ${ }^{31}$

In other words, global problems are highly complex and in order to solve them efficiently and effectively, a new form of international cooperation is needed: Transgovernmentalism. The state as a unitary actor is no longer able to deal with these issues. The principles of speciality and expertise have led government institutions to establish direct contact with their counterparts in other latitudes. At the same time, global challenges can only be addressed in a sphere of liberty where people with different interests (even contradictory interests) can join efforts to find rational solutions that avoid violent conflict. ${ }^{32}$

Some authors have argued that: "[p]olitical and economic freedoms allow individuals to form transnational associations and to influence pol-

31 Slaughter, Anne-Marie, "The Real New World Order", supra note 8, at 184.

32 Slaughter, Anne-Marie, "International Law in a World of Liberal States", supra note 8 . 
icy in light of the resulting interests, inhibiting their governments from acting violently toward one another". ${ }^{33}$

Transgovernmentalism is only possible among liberal democracies. Only if all interest groups enjoy political and economic freedoms, can these networks flourish. Formal democracy and an active engagement of civil society are essential requirements of transgovernmentalism. The state can only be disaggregated where real separation of power exists, and where all branches of government are accountable to the people generally, but especially to their own constituencies. National courts applying international law must be mindful of the interests of lawyers, pressure groups, business persons, human rights organisations and other courts, irrespective if their nationality.

With this emerging concept of sovereignty, foreign policy will be shaped by these networks and not only by the government institution in charge of foreign affairs.

Disaggregation of the State is what really differentiates the Liberal concept of judicial globalisation from that advanced by the Realist approach.

Now that the basic ideas of this kind of judicial globalisation have been expounded, a brief commentary of its implications in world governance is in order.

\section{Judicial globalisation and its implications in world governance}

Firstly, judicial globalisation would imply a shift from traditional Interstate Dispute Resolution processes to a Transnational Dispute Resolution model, which is integrated with supranational and national judicial and quasi-judicial bodies, characterised by high levels of independence from the states that have given birth to them.

The resolutions of supranational bodies would be recognised and implemented with relative ease in domestic law. But more importantly, individuals, national courts, and legal persons, other than states, would have standing in supranational fora. Access by non-state actors is the key element to this new kind of adjudication. Participation of civil society as litigants in international tribunals offers a series of advantages over IDR. As opposed to governmental representatives, private parties do not have 
to remain loyal to their nation's interests, but rather to their own individual rights. Therefore, the involvement of private parties may reduce the problem of diplomatic frictions. Since the political problem between states is eliminated, natural and legal persons are encouraged to litigate more frequently in these forums. This very fact increases the caseload of courts, which in turn, generates a robust body of jurisprudence that can be adopted not only by other supranational judicial entities, but also by domestic courts in general. "Compared to interstate dispute resolution, transnational dispute resolution tends to generate more litigation, jurisprudence more autonomous of national interests, and an additional source of pressure for compliance". ${ }^{34}$

The legal principles advanced by these courts and tribunals can be shared through formal legal channels (legal links between supranational tribunals and domestic courts as in the case of article 177 of the Treaty of Rome; judicial comity or constitutional cross-citation), or by means of more informal exchanges. Political pressure by interest groups and the exchange of shared values between judges are meta-juridical ways of consolidating this change.

Secondly, judicial globalisation would imply that a good share of international relations would be legalised, and that the margins for political manoeuvre by governmental institutions, in guiding foreign policy, would be considerably reduced, especially in the areas of human rights (individual rights) and economic liberties. However it is not clear whether this scheme of legalisation includes areas such as social, economic and cultural rights, poverty, security of states, among other important international issues. It would be a regime that only applies to liberal democracies. If that is really the case, then a huge part of the world would be let outside of its advantages. The regime would be the European experience writ large. But European institutions were viable, in part, because the nations that have formed them had a common heritage from the legal, ethical, cultural, religious and economic standpoint.

In sum, judicial globalisation as construed by this strand of Liberalism, would transform courts and tribunals around the world into discrete but significant centres of power that would dictate the canons of what the "free world" understands as fundamental individual economic and politi-

34 Keohane, Robert O. et al., "Legalized Dispute Resolution: Interstate and Transnational", supra note 7 , at 458 . 
cal liberties. These canons would not be established by Western states as such, but by one of their most important by-products: Tribunals. However, it seems that outside proponents of economic freedom and human rights, there is no interest in demonstrating that TRD is a good idea for widening a space where different cultures may broaden their dialogue and legal communication. Regarding this point, Slaughter tries to universalise the idea of transgovernmentalism, and therefore of TRD, by stating that:

Contrary to Samuel Huntington's gloomy predictions in The Clash of $\mathrm{Ci}$ vilizations and the New World Order (1996), existing government networks span civilizations, drawing in courts from Argentina to Zimbabwe and financial regulators from Japan to Saudi Arabia. The dominant institutions in these networks remain concentrated in North America and Western Europe, but their impact can be felt in every corner of the globe. ${ }^{35}$

This vision of world affairs is as value laden as Huntington's; the only difference is that the demons here are not other cultures but the holders of ideologies other than Liberalism. Slaughter is convinced that this new kind of governance may expand the community of liberal democracies. Moreover, she foresees not a world of sovereign states but a transnational polity —a 'negarchy': that is, "a liberal political order between anarchy and hierarchy in which power is checked horizontally rather than vertically" - .36

The problem with this position is not so much that liberal democracies are undesirable, but that two discourses overlap: the objective analysis that tries to describe how phenomena take place and the subjective-ethical discourse that advances a particular political agenda. This and other critiques to the Liberal approach to judicial globalisation will be developed in the following section.

Finally, these Liberals hold that this new form of adjudication seems to have an expansionary character; that is, it not only reproduce itself, but plows fertile ground for creating new legal norms, often in unintended ways. ${ }^{37}$ To acknowledge the uncertainty surrounding judicial

35 Slaughter, Anne-Marie, "The Real New World Order”, supra note 8, at 185-186.

36 Slaughter Anne-Marie, "International Law in a World of Liberal States", supra note 8 .

37 Idem. 
globalisation is a sign of prudence by these liberal authors. They are aware that that the evolution of the major European courts would not have been predicted when they were created. Both ECJ and ECHR were established to function as most IDR resolution processes. The Liberal authors assert that things are changing but do not try to appear as prophets. This approach gives them leeway to continue elaborating on their theories. The following section elaborates a critique to judicial globalisation as conceived by them.

\section{A CRITIQUE TO THE LIBERAL APPROACH}

The "new liberal order" that emerged at the end of the Cold War has increased the levels of poverty in the Third World. In 1998 there were approximately 2.801 billion people living on less than two American dollars a day. ${ }^{38}$

In 2006, this panorama has not changed for good: almost 1.1 billion people live in extreme poverty - that is they live on less than one dollar a day. ${ }^{39}$

The new global agenda seems to be more committed to the expansion of economic liberties, the repression of international security threats, and the protection of individual human rights than to addressing issues such as poverty, education, public health, cultural pluralism, and social justice.

According to Slaughter, today's international problems are: "terrorism, organized crime, environmental degradation, money laundering, bank failure and securities fraud" ${ }^{40}$ Philip Alston argues against this prioritisation of the current global agenda. Alston states that under such an international agenda, "the plight of a billion or so people living in poverty seems to become a domestic problem, or at least to have disappeared from the international agenda, perhaps to be best taken care by

38 Stiglitz, Joseph E., Globalization and Its Discontents, Nueva York, WW Norton \& Company, 2002, at 5, 253.

39 Rice, Susan E., "The Threat of Global Poverty", The National Interest, primavera de 2006.

40 Alston, Philip, "The Myopia of the Handmaidens: International Lawyers and Globalization", supra note 8, pp. 435-448, http://www.ejil.org/journal/Vol8/No3/art4. html. 
the free market". ${ }^{41} \mathrm{He}$ also points out that the liberal agenda omits such vital issues as the malnourishment of 160 million children and the terrible situation facing approximately 110 million minors, who do not go to school. ${ }^{42}$ Furthermore, it appears that human rights are important as long as they do not collide with market-oriented policies. Therefore, rights of women, children, workers, and minorities, among others, are secondary. In other words, economic, social and cultural rights are not indispensable to securing order and stability in this new world order. In short, social justice and cultural diversity are not at the top of the global agenda.

Such is the nature of the liberal global agenda, but who sets and implements it?

For Serge Sur, the United States controls the agenda. In his view, globalisation is "in reality a vehicle of the media, a convenient term to indicate American hegemony. Globalization is the ideal of a New World with no shores. In a way, it is a new form of triumph of the state, but of a type of state that stands alone in its class, and which has every intention of remaining this way". ${ }^{43}$

Liberals do not share this state-centred and hegemonic perspective. For Slaughter, it is not the United States that will set and implement the global agenda, but rather various interest groups: Bankers, lawyers, businesspeople, public interest activists, and diverse governmental authorities, including judges. ${ }^{44}$ In other words and although Slaughter does not plot it in these terms, governance will be crafted by a transnational elite, which is basically unaccountable. As Alston argues, this standpoint is disturbing not only because it implies the marginalization of governments (which are supposedly accountable at least to their own citizens) in dealing with world affairs, but because "it suggests a definitive move away from arenas of relative transparency into the back rooms, the emergence of a [regime] in which those with power consolidate it and make the decisions which will continue to determine the fate of the excluded, and the bypassing of the national political arenas to which the United

41 Idem.

42 Idem.

43 Sur, Serge, "The State between Fragmentation and Globalization", European Journal of International Law, vol. 8, núm. 3, 1997, pp. 421-434, http://www.ejil.org/ journal/Vol8/No3/art3.html.

44 Slaughter, Anne-Marie, "The Real New World Order", supra note 8, at 185-189. 
States and other proponents of the importance of healthy democratic institutions attach so much importance". ${ }^{45}$

Transgovernmentalism in general and transjudicialism as portrayed by liberals can be deemed market-oriented modes of governance, controlled either by a hegemonic power or by transnational elites.

Judicial globalisation, as envisaged by liberals, is interested in strengthening individual human rights and even international criminal law, in order to secure the development and growth of a global capitalist economy. Liberal transjudicialism is silent regarding social, economic, and cultural rights. At present, international judicial bodies have only been timidly involved in the consolidation and enforcement of social rights. This position is untenable in an increasingly impoverished world where billions of people survive in inhuman conditions.

The Liberal approach to judicial globalisation is not only indifferent to global poverty but also contemptuous toward cultural diversity. It tends to assume that Northern values are universal and should be adopted uncritically by all nations, regardless of cultural or historical differences among them.

Liberal judicial globalisation also tends to overlook some important political paradoxes that are inherent to liberal democracies. It assumes that democracy and liberalism are inseparable at any given time and place.

Slaughter's theory shares these basic shortfalls of liberal transjudicialism. It does not consider economic asymmetries between the powerful North and the poor South. She overlooks the fact that a disadvantageous economic position of a state may lead it to state-centred and nationalistic positions rather than the influence of foreign and international judiciaries. In her theory, the meaning of the so-called universal values cannot be contested, because there is no space for a contextual understanding of law in which historic and cultural factors matter. It seems that Slaughter's theory would only work well for wealthy Northern countries and not for liberal democracies in general as she argues. The global community of law would be the by-product of a North American-European dialogue, which in itself is doubtful. The US has repeatedly shown its aversion to international judicial scrutiny of US national in-

45 Alston, Philip, "The Myopia of the Handmaidens: International Lawyers and Globalization", supra note 8. 
terests. Prima facie, Slaughter's theory would work well only in emerging transnational capitalist elites.

\section{The strengthening of individual human rights as means to secure} the development and growth of a global capitalist economy: Social, economic, and cultural rights forgotten

One of the most troublesome aspects of judicial globalisation - as a liberal theory - is that, at worst, human rights are conceived as means to achieve worldwide capitalist expansion or, at best, as values that are universal and uncontested everywhere. It also tends to establish a hierarchy that places individual property rights at the top of the axiological scale related to human dignity. Slaughter's theory is silent with respect to social, economic and cultural prerogatives.

Alston has stated that with globalisation, "some human rights norms are increasingly subject to an assessment of their market friendliness in order to determine what, if any, weight will be accorded to them". ${ }^{46} \mathrm{He}$ also argues that in our contemporary world, there is a tendency to suppress trade unions, to deny primary education and health care as basic human rights, and to downplay the role of gender rights and other non-discriminatory norms. Social, economic and cultural rights are not only subordinated to other human rights standards, namely individual political and civil rights, but must demonstrate that they contribute to the enhancement of a "market-based vision of the good society". ${ }^{47}$

Indeed, there is a risk of jeopardising the social conquests that marginalized groups of society have achieved through a long and difficult historical struggle.

Although the UN Committee on Economic, Social and Cultural Rights has generally demonstrated a somewhat ambivalent attitude toward the negative effects of globalisation in the regime it oversees, it has nonetheless acknowledged that:

Taken together... and if not complemented by appropriate additional policies, globalization risks downgrading the central place accorded to human rights by the United Nations Charter in general and the Bill of Rights in particular. This is especially the case in relation to economic, social and 
cultural rights. Thus, for example, respect for the right to work and the right to just and favourable working conditions of work is threatened where there is an excessive emphasis upon competitiveness to the detriment of respect for the labour rights contained in the Covenant. The right to form and join trade unions may be threatened by restrictions upon freedom of association, restrictions claimed to be 'necessary' in a global economy, or by the effective exclusion of possibilities for collective bargaining, or by the closing off of the right to strike for various occupational and other groups. The right of everyone to social security might not be ensured by arrangements which rely entirely upon private contributions and private schemes. ${ }^{48}$

In spite of this rhetoric, it is an undisputed fact that right after the collapse of the Soviet regime, the international financial institutions (IFIs) promoted a particular set of market-oriented policies both at the national and international levels: Privatisation; deregulation, particularly of private power; healthy public finances, and the reduction of governmental intervention to a minimum in economic matters, were part of the agenda promoted by the International Monetary Fund (IMF) and the World Bank (WB). However, due to the failures of these policies in more than one nation, ${ }^{49}$ the IFIs changed their position and began supporting an effective state, rather than a minimal one, in order to pursue economic stability and development. They realised that these goals were only attainable through the promotion of the rule of law. ${ }^{50}$ But, what does the term rule of law mean to IFIs?

On the one hand, rule of law implies the developing or the strengthening of domestic legal orders that can be trusted by foreign investors. According to them, the juridical system must be able to "lower transaction costs, increase commercial certainty, create incentives for efficiency, and control crime and corruption so that businesses can focus on produc-

48 Statement by the Committee on Economic, Social and Cultural Rights, May 1998, 18th Session, in Clapham, Andrew, "Globalization and the Rule of Law", Review of the International Commission of Jurists, 1999, núm 61, pp. 17-33, http://www.business-hu manrights.org.

49 Examples of financial crises after the end of the Cold War abound, however the case of the East Asia crisis is illustrative of how these policies failed. See Stiglitz, Joseph, supra note 38, at 89-132.

50 Alston, Philip, "The Myopia of the Handmaidens: International Lawyers and Globalization", supra note 8. 
tive activities". ${ }^{51}$ On this issue, Diego García-Sayán ${ }^{52}$ has argued that the promotion of the rule of law and judicial reform in developing countries is determined by the special interests and ideology of the IFIs. A fundamental objective of these institutions is to grant assistance to governments in order to build a legal system where property rights are clear and easily ascertained. The IFIs have realised that a market economy needs a more robust regulatory framework than what was originally foreseen.

On the other hand, the fostering of the rule of law as understood by the IFIs and by some liberal scholars - although many of them may not be willing to admit it - implies that criminal matters such as money laundering, drug-trafficking, corruption, bank failure, and even genocide must be treated in transnational judicial fora, because these types of crimes have an impact on the global economy.

Interestingly enough, drug trafficking may eventually become a punishable crime under the Statute of the ICC. At the Rome Conference, a resolution was passed in order to study the possibility of including this activity as a crime within the jurisdiction of the Court. ${ }^{53}$ Furthermore, the newly elected prosecutor of the ICC, Luis Moreno Ocampo, has stated that the original idea of establishing an International Criminal Court was promoted by Trinidad and Tobago with the purpose of prosecuting drug-traffickers and that it is most likely that the Court will be able to deal with these problems in the near future. ${ }^{54}$

This kind of criminality must be dealt with internationally, not solely because it undermines human dignity and is beyond the control of a nation-state, but also because these phenomena distort the smooth development of economic integration processes. This assertion must not be read

51 Idem. Quotation taken from World Bank, From Plan to Market: World Development Report 1996 (1996), at 86.

52 Clapham, Andrew, supra note 48, at 17-33.

53 Hebel, Herman von and Robinson, Darryl, "Crimes within the Jurisdiction of the Court", The International Criminal Court: The Making of the Rome Statute. Issues, Negotiations, Results, The Hague, Kluwer Law International, 2002, pp. 85-87. See Final Act of the Conference, Resolution E, A/CONF. 183/C.1/L.76/Add. 14, at 8.

54 In an interview with a Mexican newspaper, Luis Moreno Ocampo stated: "La iniciativa original de esta Corte fue impulsada por Trinidad y Tobago, y su objetivo era justamente el tráfico de drogas. Entonces sí está previsto que en el futuro esta Corte pueda ampliar su jurisdicción y contemplar [estos] delitos". Camarena, Salvador, "La CPI no es un 'superpolicía"”, El Universal, México, 26 de abril de 2003 (interview with Luis Moreno Ocampo, Prosecutor for the International Criminal Court). 
as a derogatory expression against scholars who are indeed committed to the protection of human dignity. What is really interesting is that human dignity and economic liberties do not seem to be mutually exclusive if read in the context of grand and complex criminality.

For example, crimes against humanity and genocide may lead to, or be committed in the context of, international or intrastate conflict. Continued violence not only harms human dignity, but it also has a negative social impact (e.g. massive migration), and disrupts national or even regional economies. The drafters of the Rome Statute were worried above all things with the negative consequences that these crimes have on human dignity. However, it is a pity that contemporary international criminal law is concerned only with individual criminal responsibility and not with other legal entities' criminal liability. Why should transnational corporations not be accountable for committing these crimes? Geoffrey Robertson is right when he wonders: "Why should a multinational chemical corporation not be prosecuted (as well as its directors) for supplying poison gas in the knowledge that it will be used for a crime against humanity? Why should that company, if convicted, not be ordered to pay massive reparations to survivors and to victims' families?". ${ }^{55}$

The answer is apparently straightforward: International criminal law as currently conceived only subjects individuals, not organisations, to prosecution. But does International criminal law has an inherent impediment to deal with corporation's criminal responsibility? Or, is there a more suspicious reason for not holding corporations accountable for their involvement in the commission of a crime? Should these entities remain out of the reach of the law simply because they are considered as pillars upon which contemporary capitalist expansion rests?

As mentioned above, the liberal concept of judicial globalisation has omitted social, economic and cultural rights from the global agenda. It has been argued that these liberties cannot be realised because of their unenforceability. Actually, they have been overlooked because they distort the global economy. Scholars who have fervently supported of international judicial bodies are aware of the scarce relevance that the international community has granted to these human prerogatives, especially after the fall of the Berlin Wall.

55 Robertson, Geoffrey, Crimes against Humanity: The Struggle for Global Justice, Nueva York, The New Press, 2002, at 366. 
It is clear that for the liberal scheme social rights are unimportant. This is understandable because liberals have always preferred individual freedom to social equality. What is really surprising is that some liberal scholars are trying to equate traditional individual rights with economic freedoms in order to consolidate the new international trade regime.

This understanding of the rule of law is dangerous. Human rights and economic freedoms are not the same thing; each camp has its own regime and logic. They cannot be "sold out in the same package". This double discourse has been instrumental in furthering the popularity of the liberal agenda: Human rights are inseparable from economic liberties, or plotted differently, economic liberties are fundamental human rights. This equation is misleading.

So far, the analysis developed in this section has demonstrated not only that economic, social and cultural rights are a burden to the expansion of global capitalism, but that poverty and social injustice are not relevant issues within the liberal agenda in general and within transjudicalism in particular. The contradiction between positive rights and negative rights is a false dilemma: the enforcement of both social rights and individual rights requires the investment of large amounts of money. Even under the judicial globalisation expounded by Slaughter, where only civil and political rights are relevant, economic asymmetries among countries present an important obstacle to the validity of this theory.

According to Slaughter's idea of judicial globalisation, a global community of law is being developed all around the world, by means of supranational adjudication, constitutional cross-fertilisation, and informal meetings among judges from different nationalities. Perhaps, the main factor that triggers judicial globalisation - at least at the supranational level - is the emergence of increasingly permissive international judicial bodies that allow access and standing to non-state actors. As Slaughter argues, litigation by private parties in transnational fora generates more litigation and, consequently, more jurisprudence. While on the surface this might appear to be convincing, it must be kept in mind that transnational litigation is expensive. Would a person living on less than two dollars a day be able to litigate before the Inter-American Court of Justice? Here the problem of access to justice is not formal but meta-juridical. From a positivist standpoint, any person can make a claim in this forum. Some people would even assert that a poor peasant could have access to international justice. The question is who pays the bill? A powerful for- 
eign government? A transnational corporation? Or an influential NGO? Is the sponsor really interested in the fate of the poor individual who is looking for redress at the international level? Or does the provider of assistance have a hidden agenda more closely allied with its own interests or with power politics? Even if we admit that this sort of sponsorship is valid, we must acknowledge that these cases are rare and sporadic.

European countries spent time and money in the construction of well-functioning national courts. In the short run, this expenditure contradicted market efficiency. However, their ability to first improve their own national judicial systems, allowed them to eventually engage in a more ambitious common economic and political project.

Developing countries also need to build healthy domestic courts and tribunals. But the construction of these sorts of institutions requires financial investment and time as well as harsh choices: How much of the national income will go to food or healthcare? How much to education? How much to justice? It seems that all of these needs are important, but there are priorities: In the short run, it is far more important to eat, than to go to San José or to The Hague to litigate a human rights case or seek redress as a victim of a crime. Therefore governments of developing countries must be very prudent as to address the problem of famine and at the same time implement a strategy for establishing good and trustworthy courts. As Michael Mann has noted: "Many Southern regimes, especially Asian ones, counter that economic subsistence and social security should take priority over liberal conceptions of rights". ${ }^{56}$

\section{The contemptuous attitude of Liberal Judicial Globalisation toward cultural diversity}

The liberal view of global governance fails to consider cultural diversity around the world. Ethno-nationalism and religious resistance movements are increasingly emerging throughout the South. Human groups opposing market-oriented globalisation are at the rise. Social movements such as the Colombian FARC, the Mexican Zapatistas, and the Naxalites of India, as well as religious fundamentalist movements in

56 Mann, Michael, "Globalization, Global Conflict and September 11"; originally given as a lecture at the Russian State University for the Humanities, Moscow, September 24, 2001. Document provided by Dr. Tarak Barkawi, Centre for International Studies, University of Cambridge. 
South Asia, India, Israel and the Arab world, are phenomena that can be explained only as a response of oppressed peoples toward Northern cultural imperialism. ${ }^{57}$

Furthermore, some groups in the North as well as in the South have been excluded from the global agenda. Women, indigenous peoples, homosexuals and lesbians, and racial minorities constitute important segments of the world's civil society that have been excluded from the 'benefits' of the new global order.

Liberals view international law as a valid regime for everybody, everywhere. Its pertinence is not conditioned on cultural or historical considerations. Its aim is to be universal. This view has been contested by scholars influenced by critical legal studies, feminism, postcolonialism, indigenous rights activism, and critical race theory. They have argued that "what international law presents as universality is, in fact, based on a white Western male view of the world". ${ }^{58}$ This critique is well supported. A careful reading of the text of the Statute of Rome can shed light on this issue. As Geoffrey Robertson has noted, the Statute does not protect individuals from criminal activities, particularly from persecution on the grounds of sexual orientation. People are only protected from persecution on the grounds of gender. Robertson correctly states that Article 7 (3) of the Statute is a ridiculous clause because it establishes that: "For the purpose of this Statute, it is understood that the term 'gender' refers to the two sexes, male and female, within the context of society. The term 'gender' does not indicate any meaning different from the above". ${ }^{59}$

Robertson sarcastically asserts that this clause "means, presumably, that you can do what you like to transexuals. Persecution is a crime if directed against men as men, or women because they are female, but homosexuals and lesbians may still suffer the thumbscrew and the rack, the 'intentional and severe deprivation of fundamental rights' when it is 'within the context of society', i.e., approved by a gay-bashing government or culture. The inclusion of Article 7 (3) is a distasteful but realistic

57 Idem.

58 Knop, Karen, "Here and There: International Law in Domestic Courts", 32 N.Y.J.INT'L L. \& POL, p. 527.

59 Article 7 (3), Rome Statute of the International Criminal Court, http://www.icc now.org. 
remainder that a majority of states in 1998 favoured the withdrawal of human rights on grounds of sexual orientation". ${ }^{60}$

But the liberal understanding of international law is not only contemptuous of non-Western cultures lato sensu, it also overlooks the significance of the various existing legal cultures both within the North and the South.

According to Slaughter's theory, judges are establishing an ever-closer dialogue among them through vertical relations (supranational adjudication) and horizontal relations (constitutional cross-fertilisation and face-to-face meetings). This dialogue will lead to the creation of a global community of law, which is supposed to be more or less homogeneous and universal.

Slaughter's model assumes that even though many international instruments as well as foreign law are not binding for domestic judiciaries, transnational judicial dialogue can persuade judges of what should be regarded as good law for everyone, everywhere.

Karen Knop criticises this point of view, arguing that "the transjudicial model... assumes the interpretation of international law by domestic courts to be largely straightforward and universalising". ${ }^{61}$ But universality is not the only contested issue in Slaughter's acultural scheme; there are other problems with her approach. The authority of non-binding international law and foreign law may derive not from persuasion but from the imposition of values held by a transnational elite or the US legal system. ${ }^{62}$

The alleged universal character of these norms and the acceptance that, in some cases, they may be rightfully imposed on others, constitute a direct attack on cultural diversity that only serves to unveil the real agenda behind judicial globalisation. This is the reason why Karen Knop prefers to study this process from the lens of comparative law and not from Slaughter's perspective. As David Kennedy has argued: "International Law [and transjudicialism is not an exception] takes its project as governance, while comparative law stakes out the ground of cultural understanding". ${ }^{63}$ International law is related to a "vertical engagement of

60 Robertson, Geoffrey, supra note 55, at 360 y 361.

61 Knop, Karen, supra note 58, at 535.

62 Ibidem, at 521.

63 Ibidem, at 526. 
authority' whilst comparative law's approach has to do with a 'horizontal engagement of ideas'.

But the main critique of Slaughter's approach with respect to cultural diversity is that it does not recognise the role of culture in the legal interpretative process that takes place in domestic courts when dealing with non-binding international norms and foreign law. It seems that she shares the vision of mainstream international lawyers to whom international law has meaning but no culture. ${ }^{64}$ Maybe, it is, in fact, the other way around: International law has culture but not meaning.

For liberals, domestic judicial interpretation of international law and foreign law is not problematic. The only thing judges have to do is to mechanically integrate the imported principles into their own juridical systems. Even if these principles are not binding, they constitute arguments that can reinforce, or be linked to, existing mandatory norms of the national system. The persuasive effect of these principles may have a strong political impact on the relevant nation-state, ensuring that legislative measures will be taken to transform these imported arguments into positive law.

However, it must be borne in mind that legal interpretation is always a form of translation of meaning. It might just be the case that the very same international juridical principle or a foreign norm does not mean the same in Mexico, Britain or Japan. Context is important in interpreting norms. Interpretations of imported legal rules may vary from place to place. When interpreting legal norms, national judges are mindful not only of the domestic legal system as a whole, but they are also aware of the sociological and cultural context in which national norms are applied. To take just one example, freedom of expression is not conceived or interpreted in the same way in the United States as in Germany. This right is construed more narrowly in Germany because of the Nazi experience.

Article 5 of the German Constitution enshrines rights related to the freedom of expression. However, it clearly states that "these rights are subject to limitations in the provisions of general statutes, in statutory provisions for the protection of the youth and in the right to personal honor" ${ }^{65}$ To denigrate an ethnic group constitutes such a limitation. In

64 Ibidem, at 528.

65 Germany's Basic Law. Chapter I. Basic Rights. Article 5 (Freedom of expression). Emphasis added. 
Germany, the so-called "Auschwitz lie" has been expressed by several right-wing extremists, who basically hold that Jews were not persecuted in Nazi Germany; that is, that the Holocaust did not happen. These kinds of expressions are prohibited because they are an attack to the dignity of all the Jewish people who were assassinated by the Nazi regime. German jurisprudence has held that "the injury to the personal honor of those defamed (Jewish citizens) weighs so heavily that it takes precedence over freedom of expression". ${ }^{66}$

By contrast, freedom of expression is conceived more broadly in the United States. The First Amendment of the US Constitution only establishes that: "Congress shall make no law... abridging the freedom of speech, or of the press". ${ }^{67}$

American jurisprudence has made it clear that freedom of expression is not an absolute right. However, the RAV $v$. City of St. Paul case, ${ }^{68}$ decided by the Supreme Court in 1992, acknowledges that this broad right can take precedence over the dignity of a human who has been attacked by hateful speech.

The facts of this case took place in the City of St. Paul in 1990, where several teenagers burned a cross inside the fenced yard of a black family. The City charged the offenders under the St. Paul Bias-Motivated Crime Ordinance, which establishes that: "Whoever places on public or private property a symbol, object, appellation, characterization or graffiti, including, but not limited to, a burning cross or Nazi swastika, which one knows or has reasonable grounds to know arouses anger, alarm or resentment in others on the basis of race, color, creed, religion or gender commits disorderly conduct and shall be guilty of a misdemeanor" ${ }^{69}$

In spite of this ordinance, the trial court dismissed the count arguing that this norm was substantially overbroad and impermissibly content-based and therefore invalid under the First Amendment. Although

66 Web page of the German Embassy in Washington, DC, http://www.germany info.org/relaunch/info/archive/backgroung/speech.html.

67 See Articles in addition to, and amendment of, the Constitution of the United States of America, proposed by Congress, and ratified by the several States, pursuant to the Fifth Article of the Original Constitution. Amendment I (1791), in Gunther, Gerald and Sullivan, Kathleen M., Constitutional Law, 13a. ed., Westbury, NY, The Foundation Press, 1997, Appendix A., p. 9.

68505 U.S. 377, 112 S. Ct. 2538, 120 L. Ed. 2 d 305 (1992).

69 Gunther, Gerald and Sullivan, Kathleen M., supra note 67, p. 1115. 
the Minnesota Supreme Court reversed the trial court's resolution, the US Supreme Court held that the ordinance was unconstitutional. Justice Scalia delivered the opinion of the court and stated that: "the ordinance is facially unconstitutional in that it prohibits otherwise permitted speech solely on the basis of the subject the speech addresses". ${ }^{70}$ In other words, St. Paul could prohibit all fighting words or no fighting words at all, but could not select a subset of them based on their content.

In short, the same 'universal' rule may have different meanings depending on the sociological, historical and cultural context in which it is interpreted. Moreover, the process of translation may radically change the original meaning of the imported norm and create an entirely different opposing norm. In the decision-making process, judges can choose from a myriad of valid legal propositions in order to solve a given problem. In this way, judges do not only make a particular translation of the imported norm, they are usually enabled by their own legal system to sacrifice certain principles and values in order to advance other equally important rights (i.e. they can sacrifice individual rights in order to give prevalence to social rights). Let us imagine a 'universal law' that enshrines the sanctity of rural private property. In the Mexican context, for example, a judge may rule that communal property takes precedence over individual property. This decision would run counter to the idea of property rights as conceived in the North and would also interfere with market-oriented policies. However, the Mexican juridical order empowers judges to issue these sorts of resolutions.

Transjudicialism does not seem to admit competition between several legal interpretations of the same foreign norm, nor does it seem to be willing to admit that the prevailing domestic interpretation may annihilate the original meaning of such a norm. If the liberal theory is unwilling to accept that international and foreign legal principles might be challenged by cultural factors, then it is clear that its real purpose is to impose a particular meaning throughout the entire world.

\section{Political contradictions implied in the implementation of Liberal} Transjudicialism

Before analysing the way in which this juridical imposition may take place, it is important to point out another important shortfall in Slaugh- 
ter's theory that has more to do with political issues than with culture. She bases the importance of transjudicialism on the assertion that it furthers liberal democracy, and that liberal democracies are friendly to judicial globalisation. However, Liberalism and Democracy do not necessarily come together every time and every place. A political community may promote liberal policies without being entirely democratic, and vice versa; it may be democratic but relatively closed to foreign influence in fields such as commerce, human rights, or even transjudicial dialogue.

For example, a democratic regime such as the United States has not recognised the validity of international conventions such as the Kyoto Protocol or the Statute of Rome. The US government has continuously shown its hostility toward the ICC. John R. Bolton, US Under-Secretary for Arms Control and International Security has stated that:

For a number of reasons, the United States decided that the ICC had unacceptable consequences for our national sovereignty. Specifically, the ICC is an organization whose precepts go against fundamental American notions of sovereignty, checks and balances, and national independence. It is an agreement that is harmful to the national interests of the United States, and harmful to our presence abroad..$^{71}$

The United States, the liberal democracy par excellence, does not seem to care much about establishing a transjudicial dialogue with any court outside US territory. As Slaughter recognises, US judges have refused to comply with the so-called "judicial comity." In a trading case involving an American court and a Hong Kong court, for example, Judge Owen of the Southern District of New York declared: "I am not going to do this [to defer jurisdiction to the Hong Kong court]. I'm an American judge and this is an American agency and I will keep jurisdiction an I will direct payment into court". ${ }^{72}$

Democracy and Liberalism is not one and the same thing. The following example may be qualified as a statistical aberration, but it demonstrates not only that democracy and liberalism inhabit different realms,

71 Bolton, John R., Under Secretary for Arms Control and International Security, "The United States and the International Criminal Court", Berlín, Remarks at the Aspen Institute, 16 de septiembre de 2002. This document is available at http://www.state.gov/t/ us/rm/13538. htm.

72 Slaughter, Anne-Marie, “Judicial Globalisation”, supra note 3, at 1117 
but that democratic processes may render paradoxical outcomes. Recent elections in a South-American country illustrate this point. Venezuelan president Hugo Chávez took office in 1999 through a clean and transparent electoral process. He previously tried to assume power through a Coup d'Etat, but nobody can deny that in 1999 he had the support of the majority of the citizens of Venezuela. As the president of this country he has continuously displayed populist economic policies that are not compatible with market economy canons.

It can be concluded that judicial globalisation is a project of governance that is being advanced without regard to cultural diversity. It has also been presented as a logical consequence of the new dynamics created by globalisation, which are beyond the state's control. However, Liberals hold that states remain as important promoters of transjudicialism as long as they are liberal democracies. It has been shown that this sort of globalisation is a project of domination either by transnational elites, or by the United States of other countries or -if the trasnational elite model is preferred - of the marginalized and poor peoples around the world. In the next section, a more thorough analysis of this issue is elaborated.

\section{Judicial Globalisation as a new form of non-coercive domination of the capitalist world system over peripheral and semi-peripheral regions, in the context of emergent transnational configurations?}

In his excellent book Promoting Polyarchy: Globalization, US Intervention, and Hegemony, William I. Robinson states that:

On the eve of the twenty-first century the United States (more precisely, dominant groups in the United States) is assuming a leadership role on behalf of a transnational hegemonic configuration. Similarly, I argue, contrary to mainstream notions (particularly among realists and world system analysts) that the historical pattern of successive "hegemons" has come to an end, and that the hegemonic baton will not be passed from the United States to a new hegemonic nation-state, or even to a "regional bloc." "Pax Americana" was the "final frontier" of the old nation state system and hegemons therein. Instead, the baton will be passed in the twenty-first century to a transnational configuration. ${ }^{73}$ 
Throughout his work, Robinson argues that globalisation is redefining North-South economic and political relations. A globalised market-oriented economy is generating new dynamics in international relations. An emerging transnational elite is creating new rules of governance. From the economic perspective it is promoting neo-liberalism; from the political standpoint, the new elite's project is to consolidate political systems that function through consensual mechanisms of social control. ${ }^{74}$ Robinson stresses the consensual nature of these mechanisms as essential to achieving neo-liberal goals. In our contemporary world, it is no longer necessary to invade the territory of a state in order to achieve economic expansion. US sponsored coups d'état and the promotion of illegitimate governments in former Western colonies, which would be loyal to the great powers, are no longer viable.

Imposition as a form of domination worked in the past, but the superpowers had to pay a very high price in terms of bloodshed and social and political instability in countries where they posited their own interests. However, they were able to do this basically for two reasons. First, the world economy had not yet reached a magnitude of scale as to engender its own dynamics and logic. Second, the two superpowers - the Soviet Union and the United States - were trapped in the never-ending and ever-growing security dilemma. This situation impelled them both to search expansion, be it ideological or territorial, by whatever means were necessary, as long as they did not enter a nuclear confrontation. Today, now that the Soviet regime has fallen, the threat of total and rapid destruction of the world has simply disappeared. The United States is the only superpower left, at least in military terms. In the absence of such a fatal threat and drawing on past experiences, it seems more efficient and effective to use persuasion and non-coercive means to achieve the economic expansion sought by ruling elites in the North, but especially in the US.

Promoting polyarchy is a way in which these interests can be advanced. According to Robinson, polyarchy can be defined as a "system in which a small group actually rules and mass participation in decision-making is confined to leadership choice in elections carefully managed by competing elites". ${ }^{75}$ It is a distorted version of democracy. Its 
appeal lies in the appearance that it shares many traits of democratic governance, but polyarchy is fixed on processes and not on outcomes. It refers to electoral democracy but not to real participatory democracy. In short it is a simulation of the rule by the people. However, its impact on society is beneficial, because people feel empowered by polyarchy despite the inability to control their own destiny. Citizens cannot allege that they have not been taken in consideration. They have elected their own leaders, although they might not know that the choices have already been negotiated among national and transnational elites.

Judicial globalisation as portrayed by Slaughter is just another consensual mechanism to achieve neo-liberal goals. Its logic is similar to that of polyarchy. Apparently all people can express their points of view through a dense network of national and transnational judicial bodies. Humanity will reach a minimum consensus about the most important values that ought to be protected. A global community of law is emerging and for the first time in History, the delicate international issues that used to be addressed and settled in political fora (where the strongest prevailed) will finally be legalised. For the first time we would have an objective framework - law - to settle our disputes. Judicial globalisation pretends to be universal. Nobody is left out of this "brave new world". As in polyarchy, however, the judicial globalisation agenda has already been set, not by the peoples, but by an emerging capitalist elite. It is not surprising that social, economic and cultural rights are omitted. They run counter to market efficiency. It is only natural that the role of culture in judicial discourse is downplayed. Cultural diversity implies that any given legal principle is subject to a process of translation by the adjudicator. In this process, the original intended meaning of the norm may change; multiple competing meanings may emerge to the point where it is impossible to recognise the rule as part of the same body of law. This is the reason why liberal transjudicialism views comparative law as an obstacle for the strengthening of Northern conceptions of human rights and economic liberties, which are essential for capitalist expansion. As Michael Mann has noted: "Ideological power is wielded by those who offer meaning systems and mobilizing rituals which make plausible sense of the world we live in". ${ }^{76}$ The members of a transnational elite that is committed to the expansion of the neo-liberal project 
are those who have offered meaning systems in the context of judicial globalisation.

As with polyarchy, liberal transjudicialism focuses on procedural but not substantive issues. It does not leave room for ideological debate because the debate has been limited a priori.

However, the following question must still be answered: Is there any opportunity to contest judicial globalisation as conceived by liberals? The response is not straightforward.

Firstly, we must consider that, although judicial globalisation might be generating its own endogenous and exogenous dynamics that are independent of the will of states, it would be premature to underestimate the power of sovereign states in world politics.

Secondly, judicial globalisation is just beginning, it's evolution cannot be foretold, just as nobody in the 1960's would have predicted the paths taken by the two major European courts. They evolved, as Slaughter acknowledges, in unintended ways.

Thirdly, assuming that this nascent trend consolidates, the very same configuration of the model could offer ways of resisting the liberal understanding of judicial globalisation. Transjudicialism, like polyarchy, relies basically on an institutional framework, but not on substantive issues. Therefore, each and every judicial forum - supranational courts and tribunals, international and national judicial bodies, symposia and conferences - can be used to challenge the neo-liberal agenda.

It is a tough task but one that should be undertaken, if the world is to become a place where human dignity and diversity are truly respected. 